American Journal of Economics and Business Administration 2 (2): 157-159, 2010

ISSN 1945-5488

(C) 2010 Science Publications

\title{
The Success Story of Voluntary Retirement Scheme in National Carbon Company: A Unit of Eveready Industries India Ltd
}

\author{
${ }^{1}$ Soma Basu and ${ }^{2}$ Saroj K. Datta \\ ${ }^{1}$ Institute of Management Technology, Centre for Distance Learning, 3A, \\ Auckland Place, 7th Floor Kolkata-700 017, West Bengal, India \\ ${ }^{2}$ Faculty of Management Sciences, Mody Institute of Technology and Science, \\ Deemed University u/s 3 of the UGC Act, 1956, Lakshmangarh, Rajasthan, India
}

\begin{abstract}
Problem statement: The success story of VRS in National Carbon Company-a unit of Eveready Industries India Ltd., Kolkata, which was the first dry cell manufacturing plant in India, is an eye opener for research scholars, practicing managers, trade union leaders and for the management students. Over the years, technology was not upgraded and so the labor cost of this unit was quite high compared to the other modernized units. The management, in order to make the plant viable took drastic measures of downsizing its workforce through VRS. Approach: The study on the success of VRS in National Carbon Company was to find out the modalities adopted by management to make the VR scheme successful. Results: Downsizing alone cannot reduce labor cost for an industry. Technology upgradation along with downsizing can reduce labor cost. Revision of VR scheme time and again helped the organization to reduce the workforce from 3500-414. Conclusion: VRS cannot be made successful if introduced unilaterally. Positive response in downsizing through VRS can be obtained provided the Trade Union extends wholehearted support for the same.
\end{abstract}

Key words: Downsizing, technology upgradation, sweetener, skill obsolescence

\section{INTRODUCTION}

Background of the company: In 1905 (Wikipedia, 2005a) National Carbon Company, an erstwhile British company started marketing 6 million dry cells in India. In 1926 it had set up its first manufacturing unit at Calcutta (Wikipedia, 2005b). In 1934, National Carbon Company was registered as a 'Company' in India. In December 1951, the company was rechristened as Union Carbide India Ltd., with $51 \%$ share holding of Union Carbide Corporation (Wikipedia, 2005c), USA, a giant MNC in business of dry cells, chemicals, plastics and industrial gases with manufacturing and marketing network all over the world.

The mother plant, i.e., National Carbon Company was manufacturing various types of dry cells used in flashlights, toys and electronic equipments, besides manufacturing and marketing defense cells. During the period 1939-98 Union Carbide India Ltd., had setup 14 manufacturing units in India for manufacturing of variety of products like dry cells, flash lights, cinema carbons, industrial electrodes, chemicals and plastics, marine products and agricultural products.
Unfortunately, after the Bhopal gas leak disaster, in its agricultural products division, the company faced a set back and the Government of India axed its supply of defense cells as well as de-licensed the pesticide manufacturing unit of the agricultural products division.

Till 1972, the mother plant i.e., National Carbon Company, North Calcutta had 3500 workmen and 400 executives. It was observed that labor cost vis-à-vis per unit of dry cell cost was soaring very high compared to competitors like Novino, Nippo, Zeep, Duracell, BPL and Philips.

Corporate objectives and strategy: In order to combat escalating labor cost of the mother plant, the company took strategic decision to install technology intensive modern plants at another location in south Calcutta, Hyderabad and Chennai. In late 1990's, world class manufacturing unit of dry cells was setup at Noida, UP. Basic objective of setting-up technology based manufacturing facility was to content cost and combat competition.

Core competency: The company had core competency in carbons and metals business. However, this

Corresponding Author: Soma Basu, Institute of Management Technology, Centre for Distance Learning, 3A, Auckland Place, 7th Floor Kolkata-700 017, West Bengal, India Tel: +91 9831072379 
competency was utilized in manufacturing dry cells and battery component units at Calcutta, Hyderabad and Mumbai.

Strategic planning: Union Carbide India, Ltd. being a cash-rich company undertook a strategic plan to downsize the mother plant through investment in technology upgradation, material substitution and Voluntary Retirement Scheme (VRS), in respect of skill redundant workmen. Adequate financial resources were allocated for reduction of surplus workforce through VRS on humanitarian considerations at its mother plant. Thus, in one hand production capacity was enhanced in newly established technology based two other plants, at Calcutta and Hyderabad, technology upgradation of the Chennai plant and world class manufacturing unit at Noida, UP, on the other hand labor intensive mother plant where labor cost for per unit of production was highest was downsized gradually through VRS.

Organization structure, employee management and leadership: Traditionally, the mother plant had tall organizational structure with variety of hierarchy, which was contributing to disproportionate cost in terms of managerial remuneration and benefits.

In order to curtail the employee cost, organization structure was restructured to make it a flat organization by cutting down the levels as far as possible and increasing the span of supervision and control of the employees.

With regard to employee management, extensive training programme on multiskilling was introduced for the workmen and quality and qualification of the first line supervisors was improved to have better employee management at reduced cost.

In post Bhopal period as Union Carbide Corporation withdrew its research and development support for manufacturing of dry cells, the company took technology support from Japan to continue its operations. Thus, managerial style of leadership was changed from USA style to Japanese style of management. Extensive TQM programme and QC concept were introduced in regard to operations and materials management with a view of surviving in highly competitive dry cell market.

\section{MATERIALS AND METHODS}

Focus issue: In order to trim the workforce VR scheme was first introduced in National Carbon Company in 1975. Since the response to the scheme was very sluggish and the management was getting impatient to reduce workforce particularly in the context of lack of defense order and manufacturing facilities of special type of batteries in newly established plants, the VR scheme was revised seven times between 1976 and 1998. The VR scheme of 1993 had an upper limit of 4,516 USD (1USD = Rs. 31, 1993) (CheapBooks.com, 1995) per workmen did not give adequate response. Hence, in 1997, it was enhanced to 5,555 USD (1USD = Rs. 36, 1997) (EconomyWatch, 1999). Despite this management could not achieve the desired reduced level of workforce. Therefore in 1999 a 'sweetener' was introduced as per the following formula:

(A) 3 month's (Basic + DA) for each year of completed service

or

(B) (Basic + DA) for months of balance service

or

(C) 11627 USD (1USD = Rs. 43, 1999) (FORECASTCHART.com, 2008)

Whichever is least.

The sweetener has been treated as Exgratia amount for which Income Tax is payable by the workman opting for VRS.

\section{RESULTS}

Gradually, revision of VR scheme could ultimately reduce the workmen strength from 3500-414 while manufacturing of variety of dry cells was restricted to technology based single product i.e., PLM only.

\section{DISCUSSION}

Salient features of the success story: Salient features of the success story are as follows:

- The trade unions and the opinion makers were convinced by the HR department as well as by the floor level supervisors regarding necessity of technology change, reduction of per unit labor cost in the context of stiff competition from Novino and Nippo and reduction of surplus workmen.

- Some workman opted for VRS on their own, as they required hard cash to repay loans or to buy landed property or to fulfill family commitments. A large number of up-country workmen from Jharkhand, Bihar and eastern UP were allured towards VRS as they felt that VR money could be 
utilized in purchase of land in native place where they wanted to settle down ultimately.

- Due to continuous counseling and transparency regarding technology change and difficulties to survive in the highly competitive market, many employees realized that time would come soon when the company would not be able to produce dry cell due to increasing labor cost. Some people realized that in the context of ensuing modernization of the plant they could reach dead end of skill obsolescence. Therefore, they preferred to exit from the company through VRS as early as possible.

- In the apprehension of closure of this unit when the company started modernization of their Hyderabad and Taratala plant as well as commissioning of world class manufacturing unit at Noida, a large number of employees wanted to protect their hard earned money i.e., Provident fund and gratuity. As such they preferred to opt for early retirement and invest the amount in secured agencies.

- A section of workmen believed that the VR amount offered by the company along with the sweetener was more attractive than other neighboring industry who were downsizing through VR, hence, they did not hesitate to opt for VRS.

- A large population was interested in starting their own business and workshop. This happened mostly in case of engineering workmen who were ITI trained. They preferred to opt for VR and utilize the sum in business and workshop.

- Almost 50\% of the workmen of this plant hailed from UP, Bihar, Jharkhand and Orissa who were compelled to maintain dual establishments. These sections of population preferred to wrap their Kolkata establishment and enjoy retired life at native place.

\section{CONCLUSION}

The success story of VRS at national carbon company depended largely due to the effort of management and trade unions. Some managers even took up an MBO to downsize their departmental employees. The management took help of influential political leaders who mattered for existing trade unions and could prevail upon some of the rebellion union leaders to downsize workforce. The other factor, which helped the company to downsize this plant, was advance age group of the workmen, who preferred to get away from monotony of work and wanted to be on their own.

\section{REFERENCES}

CheapBooks.com, 1995. Universal Currency Convertor. http://www.xe.com/ucc/convert.cgi?Amount=1\&Fr om $=U S D \& T o=I N R \&$ image $. x=14 \&$ image,$y=1$

EconomyWatch, 1999. Rupees, Rupee Currency, Indian Currency, Indian Rupee Exchange Rate. http://www.economywatch.com/exchangerate/rupee.html

FORECAST-CHART.com, 2008. Indian Rupee Rate Forecast. http://www.forecast-chart.com/usd-indian-rupee.html Wikipedia, 2005a. Eveready Industries. http://en.wikipedia.org/wiki/Eveready_Industries \#History

Wikipedia, 2005b. Eveready Industries. http://en.wikipedia.org/wiki/Eveready_Industries\# Milestones

Wikipedia, 2005c. Union Carbide India Limited. http://en.wikipedia.org/wiki/Union_Carbide_India_ Limited 